\title{
Sphingobacterium kitahiroshimense sp. nov., isolated from soil
}

\author{
Correspondence \\ Hidetoshi Matsuyama \\ matsuyama@tspirit.tokai-u.jp
}

\author{
Hidetoshi Matsuyama, ${ }^{1}$ Hiromichi Katoh, ${ }^{1}$ Takahumi Ohkushi, ${ }_{1}^{1}$ \\ Atsushi Satoh, ${ }^{1}$ Kazuyoshi Kawahara ${ }^{2}$ and Isao Yumoto ${ }^{3}$
${ }^{1}$ Department of Bioscience and Technology, School of Biological Science and Engineering, Tokai University, Minamisawa, Minami-ku, Sapporo 005-8601, Japan
${ }^{2}$ Department of Applied Material and Life Science, College of Engineering, Kanto Gakuin University, Rokuurahigashi, Kanazawa-ku, Yokohama 236-8501, Japan
${ }^{3}$ Research Institute of Genome-based Biofactory, National Institute of Advanced Industrial Science and Technology (AIST), Tsukisamu-Higashi, Toyohira-ku, Sapporo 062-8517, Japan

\begin{abstract}
A novel exopolysaccharide-degrading bacterium, designated strain $10 \mathrm{C}^{\top}$, was isolated from soil from Kitahiroshima city, Hokkaido, Japan. The novel isolate was Gram-negative, strictly aerobic and chemoheterotrophic. The DNA G+C content was $36.9 \mathrm{~mol} \%$. Major fatty acids were $\mathrm{C}_{16: 1} \omega 7 c$, iso- $\mathrm{C}_{15: 0} 2-\mathrm{OH}$, iso- $\mathrm{C}_{15: 0}$ and iso- $\mathrm{C}_{17: 0} 3-\mathrm{OH} .16 \mathrm{~S}$ rRNA gene sequence analysis and chemotaxonomic and morphological data indicated that the novel strain clearly belonged to the genus Sphingobacterium. Based on phenotypic properties and DNA-DNA hybridization data, the new isolate was assigned to the genus Sphingobacterium as Sphingobacterium kitahiroshimense sp. nov. The type strain is $10 \mathrm{C}^{\top}\left(=\mathrm{JCM} 14970^{\top}=\mathrm{NCIMB} 14398^{\top}\right)$.
\end{abstract}

There have been many reports of micro-organisms that produce exopolysaccharides (EPS). In this study, we attempted to isolate novel polysaccharide-degrading bacteria and to obtain the oligosaccharides in order to elucidate the structure of the EPS. Isolate $10 \mathrm{C}^{\mathrm{T}}$ had the ability to degrade polysaccharides and was found to be a novel Sphingobacterium-like strain. The genus Sphingobacterium can be distinguished from the genus Flavobacterium by the presence of high concentrations of sphingophospholipids (Yabuuchi et al., 1983). In this study, we examined the physiological, biochemical and chemotaxonomic characteristics and phylogeny of strain $10 \mathrm{C}^{\mathrm{T}}$. DNA-DNA relatedness data showed that the strain should be classified as a novel species of the genus Sphingobacterium.

In order to isolate polysaccharide-degrading bacteria, we analysed a soil sample that was collected from Kitahiroshima, Hokkaido, Japan. The sample was suspended in $10 \mathrm{ml}$ medium containing $\left(1^{-1}\right): 0.1 \mathrm{~g} \mathrm{KNO}_{3}$, $1 \mathrm{~g}$ yeast extract, $0.1 \mathrm{~g}$ EPS produced by Halomonas sp. strain su3k3 and $10 \mathrm{ml}$ trace element solution (Patel, 1984), at $\mathrm{pH}$ 7.8. Strain su3k3 was isolated from a sediment sample taken from the Pacific Ocean as a polysaccharide producer (unpublished data). This medium

Abbreviations: El, electron ionization; EPS, exopolysaccharides.

The GenBank/EMBL/DDBJ accession number for the 16S rRNA gene sequence of Sphingobacterium kitahiroshimense sp. nov. $10 C^{\top}$ is AB361248. was incubated at $25{ }^{\circ} \mathrm{C}$ with shaking at 150 r.p.m. After incubation for several days, a portion of the suspension was transferred into $10 \mathrm{ml}$ fresh medium and reincubated. After three successive transfers, the suspension was plated onto solid medium to isolate pure cultures. The resulting isolates were checked to determine whether they degraded EPS by gel chromatography (HW-40S; Toyopearl) of both the cultural and enzyme reaction broth. Of the strains isolated, strain $10 \mathrm{C}^{\mathrm{T}}$, which showed good EPS degradation, was selected for further study. To investigate the morphological and physiological characteristics of the novel isolate, strain $10 \mathrm{C}^{\mathrm{T}}$ was cultivated aerobically at $25{ }^{\circ} \mathrm{C}$ on nutrient agar (Difco). Cell morphology was observed using a scanning electron microscope.

Strain $10 \mathrm{C}^{\mathrm{T}}$ was tested for a range of phenotypic properties using standard procedures (Komagata, 1985). Growth at different temperatures $\left(4-40{ }^{\circ} \mathrm{C}\right)$ was tested using nutrient broth (Difco). Additional biochemical tests were performed with the API 20NE test kit (bioMérieux) and the Biolog GN MicroPlate method as described by the manufacturers. The analysis of quinones was carried out by the identification services of TechnoSuruga Laboratory Co., Ltd, Shizuoka, Japan.

Sphingolipid analysis was performed according to Kawahara et al. (2000). Cellular lipids were extracted by chloroform/methanol $(2: 1, \mathrm{v} / \mathrm{v})$ and chloroform/methanol $(1: 3, \mathrm{v} / \mathrm{v})$ and both fractions were combined. An aliquot of this lipid fraction was hydrolysed with $0.1 \mathrm{M} \mathrm{NaOH}$ $\left(100{ }^{\circ} \mathrm{C}, 30 \mathrm{~min}\right)$. The alkaline-stable lipids were extracted 
with acetone and the acetone-insoluble fraction was prepared. The non-treated lipid fraction and acetoneinsoluble fraction were methanolysed with $1 \mathrm{M} \mathrm{HCl} /$ methanol $\left(100{ }^{\circ} \mathrm{C}, 5 \mathrm{~h}\right)$ and the sphingosine molecules liberated were peracetylated by pyridine/acetic anhydride $(1: 1, \mathrm{v} / \mathrm{v})$. The peracetylated derivatives were analysed by a GLC equipped with a CBP1 capillary column with a temperature programme of $200{ }^{\circ} \mathrm{C}$ for $5 \mathrm{~min}$ and heating (at $5{ }^{\circ} \mathrm{C} \mathrm{min}{ }^{-1}$ ) to $300{ }^{\circ} \mathrm{C}$.

Fatty acid analysis was carried out by TechnoSuruga Laboratory Co., Ltd, Shizuoka, Japan. For the fatty acid analysis, strain $10 \mathrm{C}^{\mathrm{T}}$ was grown in nutrient broth at $25^{\circ} \mathrm{C}$ for $24 \mathrm{~h}$. The cellular fatty acid profile of isolate $10 \mathrm{C}^{\mathrm{T}}$ was determined by using a Microbial ID system equipped with a GC and version 5.0 of the aerobic library (Microbial ID, 1993) according to a standard protocol (Paisley, 1996).

DNA was prepared from bacterial cells according to the method of Marmur (1961). The G $+C$ content of the DNA was determined using the method of Tamaoka \& Komagata (1984). Levels of DNA-DNA relatedness were determined fluorometrically according to the method of Ezaki et al. (1989) using photobiotin-labelled DNA probes and microplates.

The 16S rRNA gene was amplified by using the PCR method with primers $9 \mathrm{~F}$ and 1510R. The PCR product, approximately $1.5 \mathrm{~kb}$ in size, was sequenced by the dideoxynucleotide chain-termination method, using a BigDye Terminator v.3.0 cycle sequencing ready kit (Applied Biosystems) and a DNA sequencer (ABI Prism 3100). Primers 9F, 339F, 785F, 1099F, 536R, 802R and $1242 \mathrm{R}$ were used in the gene sequencing reaction (Nakagawa \& Kawasaki, 2001). Multiple alignments of the sequences were performed and the nucleotide substitution rate ( $K_{\text {nuc }}$ value) was calculated. A phylogenetic tree was constructed by the neighbour-joining method (Kimura, 1980; Saitou \& Nei, 1987) using the ClUSTAL W program (Thompson et al., 1994). Sequence similarity was calculated by using the GENETYX program (Software Development).

Isolate $10 \mathrm{C}^{\mathrm{T}}$ formed round, wet, off-white colonies which turned yellow after a few days. Cells of the bacterium were short rods, $0.5-0.6 \mu \mathrm{m}$ wide and $0.6-0.8 \mu \mathrm{m}$ long and were non-motile. The predominant menaquinone detected was MK-7. The results of some physiological tests for strain $10 \mathrm{C}^{\mathrm{T}}$ are given in the species description. Phenotypic properties of strain $10 \mathrm{C}^{\mathrm{T}}$ and reference strains of the genus Sphingobacterium are compared in Table 1.

For sphingolipid analysis, peracetylated derivatives from the methanolysate were analysed by GLC-MS. A peak with a retention time two minutes earlier than the standard peracetylated 18:0 dihydrosphingosine gave the electron ionization (EI)-mass spectrum shown in Fig. 1. The fragment ion at $m / z 144$ was assigned to the C-1/C-2

Table 1. Differential phenotypic characteristics of strain $10 C^{\top}$ and the type strains of other species of the genus Sphingobacterium

Strains: 1, Sphingobacterium kitahiroshimense sp. nov. $10 \mathrm{C}^{\mathrm{T}}$; 2, S. faecium JCM $21820^{\mathrm{T}}$; 3, S. canadense CR11 $1^{\mathrm{T}}$; , S. daejeonense TR6-04 $4^{\mathrm{T}}$; 5, S. spiritivorum NBRC $14948^{\mathrm{T}}$; 6, S. multivorum NBRC $14947^{\mathrm{T}}$; 7, S. mizutaii NBRC $14946^{\mathrm{T}}$; 8, S. thalpophilum NBRC $14963^{\mathrm{T}}$; 9 , S. antarcticum MTCC $675^{\mathrm{T}}$; 10, S. heparinum NBRC $12017^{\mathrm{T}}$; 11, S. piscium NBRC $14985^{\mathrm{T}}$. +, Positive; -, negative; v, variable; ND, no data available. Data for taxa 2-11 are from the descriptions given by Mehnaz et al. (2007).

\begin{tabular}{|c|c|c|c|c|c|c|c|c|c|c|c|}
\hline Characteristic & 1 & 2 & 3 & 4 & 5 & 6 & 7 & 8 & 9 & 10 & 11 \\
\hline \multicolumn{12}{|l|}{ Growth at: } \\
\hline $5{ }^{\circ} \mathrm{C}$ & + & + & - & - & - & - & - & - & + & + & + \\
\hline \multicolumn{12}{|l|}{ Hydrolysis of: } \\
\hline Aesculin & + & + & + & - & + & + & + & + & + & + & + \\
\hline Gelatin & - & - & + & - & - & - & - & - & + & - & - \\
\hline \multicolumn{12}{|l|}{ Assimilation of: } \\
\hline L-Rhamnose & - & + & - & - & + & + & - & + & + & ND & $\mathrm{ND}$ \\
\hline L-Arabinose & - & + & + & - & - & + & $\mathrm{V}$ & + & + & + & - \\
\hline D-Mannitol & - & - & - & - & + & - & - & - & + & ND & ND \\
\hline Melibiose & + & + & + & + & + & + & + & + & - & $\mathrm{ND}$ & $\mathrm{ND}$ \\
\hline Glycerol & - & + & + & - & $\mathrm{V}$ & - & - & + & + & ND & $\mathrm{ND}$ \\
\hline Sucrose & + & + & + & - & + & + & + & + & - & + & + \\
\hline $\begin{array}{l}\text { DNA G +C content } \\
(\mathrm{mol} \%)\end{array}$ & 36.9 & 37.3 & 40.5 & 38.7 & 39 & $39.9-40.5$ & $39.3-40.0$ & $44.0-44.2$ & 39.3 & 42.3 & $41.1-42.1$ \\
\hline
\end{tabular}




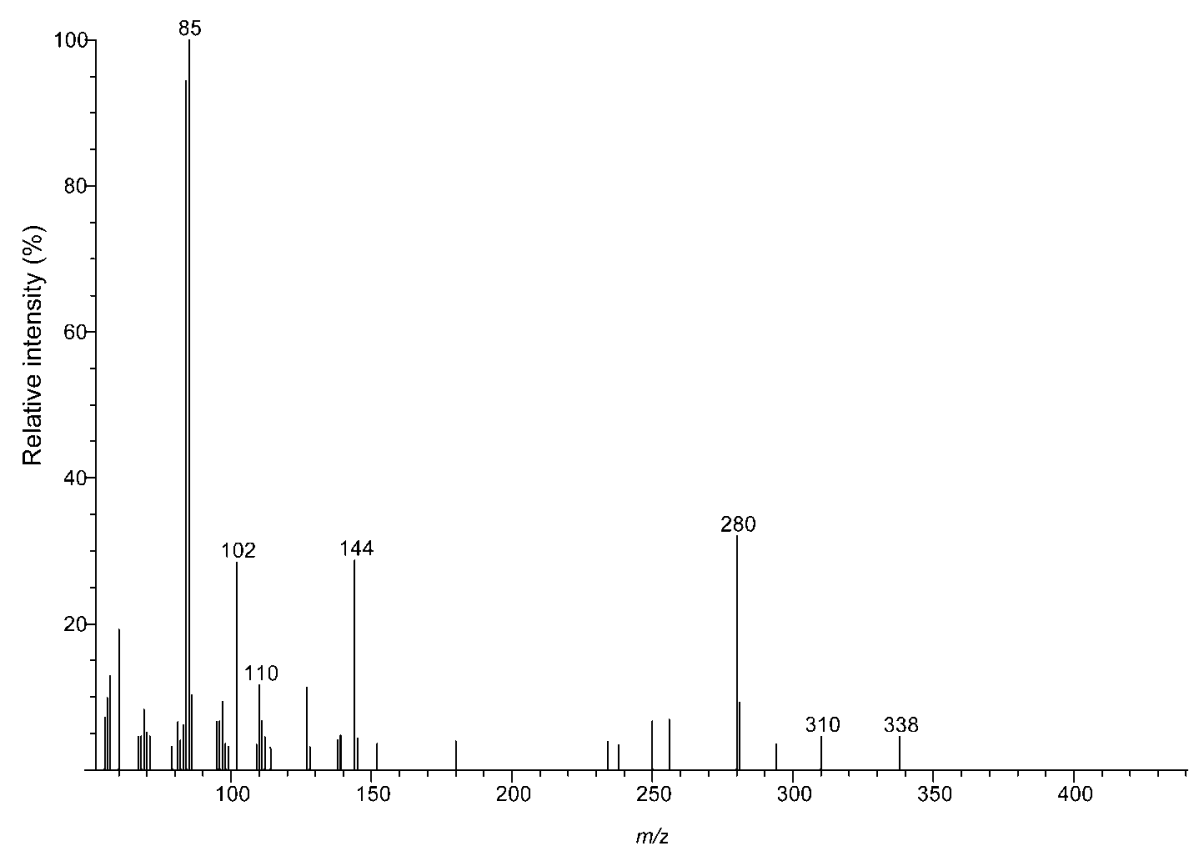

Fig. 1. El-MS spectrum of the peracetylated derivative of branched-17:0 dihydrosphingosine of Sphingobacterium kitahiroshimense sp. nov. $10 \mathrm{C}^{\top}$. This was analysed by a GLC equipped with a capillary column CBP1 with a temperature program of $200{ }^{\circ} \mathrm{C}$ for $5 \mathrm{~min}$ followed by heating $\left(\right.$ at $5{ }^{\circ} \mathrm{C} \mathrm{min}^{-1}$ ) to $300{ }^{\circ} \mathrm{C}$.

moiety of the peracetylated derivative. The fragment ion at $\mathrm{m} / \mathrm{z} 280$ was deduced to be derived from the cleavage of C-1 and C-2 and the subtraction of acetic acid (60 Da). These results indicated that the derivative detected by GLC-MS was peracetylated branched-17:0 dihydrosphingosine, which is the main sphingosine usually found in species of the genus Sphingobacterium.

The fatty acid content of strain $10 \mathrm{C}^{\mathrm{T}}$ was as follows: iso$\mathrm{C}_{15: 0} 2-\mathrm{OH}$ and $\mathrm{C}_{16: 1} \omega 7 c$ (summed feature 3 ), $40.28 \%$; iso- $\mathrm{C}_{15: 0}, 28.89 \%$ and iso- $\mathrm{C}_{17: 0} 3-\mathrm{OH}, 12.83 \%$. The fatty acid profile of strain $10 \mathrm{C}^{\mathrm{T}}$ clearly resembled those previously determined for other strains of the genus Sphingobacterium (Mehnaz et al., 2007).

The almost-complete $16 \mathrm{~S}$ rRNA gene sequence of strain $10 \mathrm{C}^{\mathrm{T}}$, which consisted of $1490 \mathrm{bp}$, was compared with all other known $16 \mathrm{~S}$ rRNA gene sequences and a phylogenetic tree was constructed using related taxa. The phylogenetic tree indicated that strain $10 \mathrm{C}^{\mathrm{T}}$ belonged to the genus Sphingobacterium (Fig. 2). The $16 \mathrm{~S}$ rRNA gene sequence similarity of strain $10 \mathrm{C}^{\mathrm{T}}$ to Sphingobacterium faecium JCM $21820^{\mathrm{T}}$ was $98.6 \%$. According to $16 \mathrm{~S}$ rRNA gene sequence analysis, strain $10 \mathrm{C}^{\mathrm{T}}$ was a member of the genus Sphingobacterium.

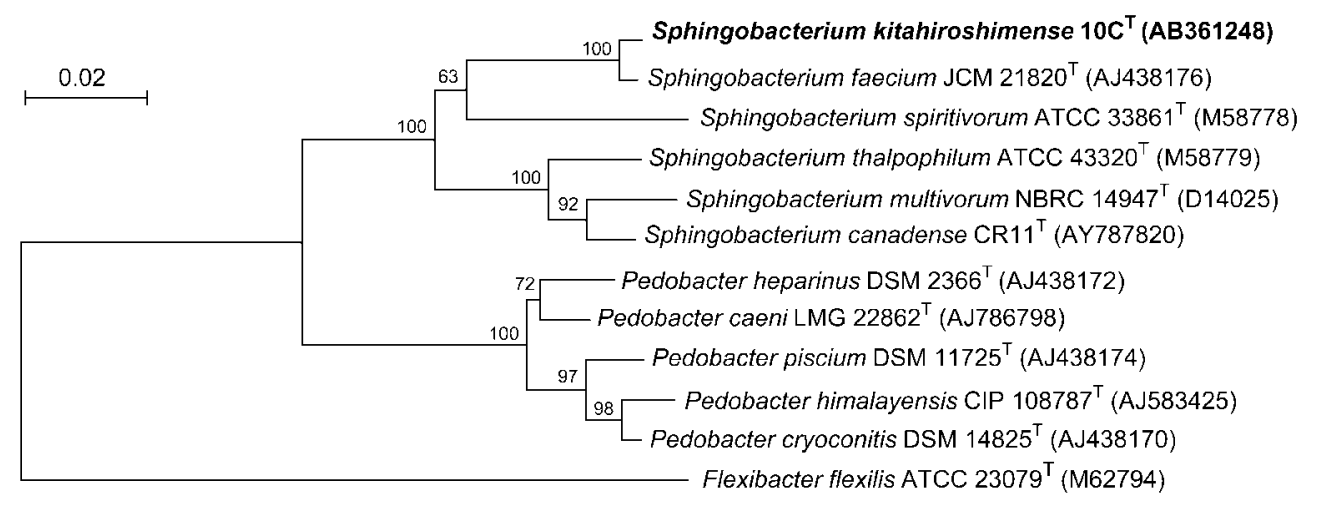

Fig. 2. Phylogenetic tree derived from $16 \mathrm{~S}$ rRNA gene sequence data for Sphingobacterium kitahiroshimense sp. nov. $10 C^{\top}$, other species of the genus Sphingobacterium and other related organisms. Bar, $0.02 K_{\text {nuc }}$. 
The genomic relatedness between strain $10 \mathrm{C}^{\mathrm{T}}$ and the most closely related strain, S. faecium JCM $21820^{\mathrm{T}}$ (Takeuchi \& Yokota, 1992), was determined by DNA-DNA hybridization analysis. The DNA-DNA relatedness of strain $10 \mathrm{C}^{\mathrm{T}}$ with S. faecium JCM $21820^{\mathrm{T}}$ was $43.6 \%$ and the reciprocal value was $31.3 \%$. On the basis of the above results, strain $10 \mathrm{C}^{\mathrm{T}}$ was considered to represent a novel species.

Strain $10 C^{\mathrm{T}}$ differed from $S$. faecium, in that the novel strain gave a negative result for the following phenotypic characteristics: utilization of L-arabinose, L-rhamnose and glycerol and detection of esterase (C4), cystine arylamidase, chymotrypsin and $\beta$-galactosidase.

The DNA G $+C$ content of strain $10 C^{\mathrm{T}}$, determined using a HPLC method, was $36.9 \mathrm{~mol} \%$. This value was almost consistent with the $\mathrm{G}+\mathrm{C}$ content of members of the genus Sphingobacterium, which ranges between 37.3 and $44.2 \mathrm{~mol} \%$ (Mehnaz et al., 2007).

On the basis of this polyphasic taxonomic analysis, the new isolate is deemed to represent a novel species for which the name Sphingobacterium kitahiroshimense sp. nov. is proposed.

\section{Description of Sphingobacterium kitahiroshimense sp. nov.}

Sphingobacterium kitahiroshimense (kita.hi.ro.shim.en'se. N.L. neut. adj. kitahiroshimense pertaining to Kitahiroshima city, where the type strain was isolated).

Aerobic, Gram-negative, oxidase- and catalase-positive, nonspore-forming, rod-shaped cells. Cells are $0.6-0.8 \mu \mathrm{m}$ long, $0.5-0.6 \mu \mathrm{m}$ in diameter and are non-motile. Circular, entire, low convex, smooth colonies develop on nutrient agar after 2 days. A yellow or creamy white, non-fluorescent pigment is produced on nutrient agar. The temperature range for growth is $4-37{ }^{\circ} \mathrm{C}$, no growth occurs at temperatures of $42{ }^{\circ} \mathrm{C}$ or above. Gives a positive result in tests for the hydrolysis of aesculin. Urease, alkaline phosphatase, acid phosphatase, $\alpha$ glucosidase, $\beta$-glucosidase, $\alpha$-galactosidase and $\alpha$-mannnosidase activities are detected. Positive result in the GN2 Biolog test for the following substrates: dextrin, Tween 40 , Tween 80 , cellobiose, $\mathrm{N}$-acetylglucosamine, D-fructose, D-galactose, gentiobiose, $\alpha$-D-glucose, $\alpha$-D-lactose, maltose, D-mannose, melibiose, raffinose, L-rhamnose, sucrose, trehalose, turanose, $\alpha$-ketovaleric acid, L-alanine, L-glutamic acid, L-threonine, Lproline and L-serine. Acid is produced from trehalose, raffinose, L-arabinose and L-xylose. Gives a negative result in tests for indole production, hydrolysis of gelatin and nitrate reduction. Arginine dihydrolase activity is not detected. The activities of DNase, esterase (C4), lipase (C4), cystine arylamidase, trypsin, chymotrypsin, $\beta$-galactosidase and fucosidase are not detected. Cannot utilize citrate, Larabinose, L-histidine, adonitol, erythritol, L-fucose, Dsorbitol, xylitol, formic acid, D-gluconic acid, DL-lactic acid, malonic acid, inosine or glycerol. Acid is not produced from rhamnose. Contains branched-17:0 dihydrosphingosine as the main sphingosine. Predominant fatty acids are iso- $\mathrm{C}_{15: 0}$ $2-\mathrm{OH}$ and/or $\mathrm{C}_{16: 1} \omega 7 c$ (summed feature 3 ), $40.28 \%$; iso-
$\mathrm{C}_{15: 0}, 28.89 \%$ and iso- $\mathrm{C}_{17: 0} 3-\mathrm{OH}, 12.83 \%$. The DNA G + C content of the type strain is $36.9 \mathrm{~mol} \%$ (HPLC method).

The type strain, $10 \mathrm{C}^{\mathrm{T}}\left(=\mathrm{JCM} 14970^{\mathrm{T}}=\mathrm{NCIMB} 14398^{\mathrm{T}}\right)$, was isolated from soil from Kitahiroshima city, Japan.

\section{References}

Ezaki, T., Hashimoto, Y. \& Yabuuchi, E. (1989). Fluorometric deoxyribonucleic acid-deoxyribonucleic acid hybridization in microdilution wells as an alternative to membrane filter hybridization in which radioisotopes are used to determine genetic relatedness among bacterial strains. Int J Syst Bacteriol 39, 224-229.

Kawahara, K., Moll, H., Knirel, Y. A., Seydel, U. \& Zaehringer, U. (2000). Structural analysis of two glycosphingolipids from the lipopolysaccharide-lacking bacterium Sphingomonas capsulata. Eur J Biochem 267, 1837-1846.

Kimura, M. (1980). A simple method for estimating evolutionary rates of base substitutions through comparative studies of nucleotide sequences. J Mol Evol 16, 111-120.

Komagata, K. (1985). Bacteria (1) - the aerobic bacteria. In Classification and Identification of Microorganisms, vol. 2, pp. 99161. Edited by T. Hasegawa. Tokyo: Gakkai Shuppan (in Japanese).

Marmur, J. (1961). A procedure for the isolation of deoxyribonucleic acid from microorganisms. J Mol Biol 3, 208-218.

Mehnaz, S., Weselowski, B. \& Lazarovits, G. (2007). Sphingobacterium canadense sp. nov., an isolate from corn roots. Syst Appl Microbiol 30, 519-524.

Microbial ID (1993). Microbial Identification System Operating Manual, version 4. Newark, DE: MIDI, Inc.

Nakagawa, K. \& Kawasaki, H. (2001). Determination method of $16 \mathrm{~S}$ rRNA gene sequence. In The Isolation and Characterization of Actinomycetes, pp. 88-117. Edited by The Society for Actinomycetes. Japan: Business Center for Academic Societies.

Paisley, R. (1996). MIS Whole Cell Fatty Acid Analysis by Gas Chromatography Training Manual. Newark, DE: MIDI, Inc.

Patel, G. B. (1984). Characterization and nutritional properties of Methanothrix concilii sp. nov., a mesophilic aceticlastic methanogen. Can J Microbiol 30, 1383-1396.

Saitou, N. \& Nei, M. (1987). The neighbor-joining method: a new method for reconstructing phylogenetic trees. Mol Biol Evol 4, 406-425.

Takeuchi, M. \& Yokota, A. (1992). Proposals of Sphingobacterium faecium sp. nov., Sphingobacterium piscium sp. nov., Sphingobacterium heparinum comb. nov., Sphingobacterium thalpophilum comb. nov. and two genospecies of the genus Sphingobacterium and synonymy of Flavobacterium yabuuchiae and Sphingobacterium spiritivorum. J Gen Appl Microbiol 38, 465-482.

Tamaoka, J. \& Komagata, K. (1984). Determination of DNA base composition by reversed-phase high-performance liquid chromatography. FEMS Microbiol Lett 25, 125-128.

Thompson, J. D., Higgins, D. G. \& Gibson, T. J. (1994). CLUSTAL W: improving the sensitivity of progressive multiple sequence alignment through sequence weighting, position-specific gap penalties and weight matrix choice. Nucleic Acids Res 22, 4673-4680.

Yabuuchi, E., Kaneko, T., Yano, I., Moss, C. W. \& Miyoshi, N. (1983). Sphingobacterium gen. nov., Sphingobacterium spiritivorum comb. nov., Sphingobacterium multivorum comb. nov., Sphingobacterium mizutae sp. nov., and Flavobacterium indologenes sp. nov.: glucosenonfermenting gram-negative rods in CDC groups IIK-2 and IIb. Int J Syst Bacteriol 33, 580-598. 